\title{
Improving grassland profitability in the Mid-continental USA by breeding for improved forage digestibility: lessons learned and applications to South American grasslands
}

\author{
Kenneth Paul Vogel ${ }^{1}$, Cesar Heraclides Behling Miranda ${ }^{2}$
}

\footnotetext{
${ }^{1}$ Agricultural Research Service (ARS/USDA) Grain, Forage and Bioenergy Research Unit. 314 Biochemistry Hall, University of Nebraska, Lincoln NE, 68583-0737.

2 Embrapa Labex-USA-Bioenergy and Embrapa Beef Cattle (CP 154, 70002-970, Campo Grande, MS). 215 Biochemistry Hall, University of Nebraska. Lincoln NE, 68583-0737.
}

\begin{abstract}
In the early 1970's research was initiated by the cooperative USDA-ARS and University of Nebraska grass breeding program to develop perennial grasses adapted to the mid-continental USA with improved forage quality. The initial breeding and animal evaluation work focused on switchgrass (Panicum virgatum) but has since expanded to several other warmand cool-season perennial grasses. The in vitro dry matter digestibility (IVDMD) test was selected as the measure of forage quality that was used in the breeding work because of its previous successful application on improving bermudagrass (Cynodon dactylon). In all of the grass species that we have studied to date, there is genetic variability for IVDMD and forage yield. IVDMD is a heritable trait with narrow sense heritability's ranging from 0.2 to 0.4 which are similar to heritability's for forage yield. If significant improvements or difference in IVDMD (> 1\%) can be detected in small plot trials $(\mathrm{r}=6)$, differences in cattle gains among experimental strains or cultivars can be demonstrated in grazing trials. Averaged over both cool- and warm-season grasses, a $1 \%$ increase in in vitro dry matter digestibility (IVDMD) generally leads to a $3.2 \%$ increase in average daily gains of beef cattle. Because increased IVDMD generally does not result in a decrease in forage yield, this results in a net increase in animal production per hectare of land.
\end{abstract}

Key Words: digestibility, economics, forage, grasses, pasture, quality

\section{Incrementos na lucratividade de pastagens no Centro Continental dos Estados Unidos da America do Norte pelo melhoramento para melhor digestibilidade de forragens: lições aprendidas e implicações para pastagens na América do Sul}

\begin{abstract}
RESUMO - No início dos anos 1970 foi iniciado um projeto cooperativo entre o Agricultural Research Service, do USDA, e a Universidade de Nebraska, para programa de melhoramento genético visando o desenvolvimento de gramíneas perenes com melhor qualidade de forragem e adaptadas ao centro continental dos Estados Unidos. Os estudos iniciais centraram-se em switchgrass (Panicum virgatum), mas depois foram extendidos a outras gramíneas perenes de estação fria e quente. A digestibilidade in vitro da matéria orgânica (DIVMO) foi selecionada como medida da qualidade, uma vez que já havia sido aplicada com sucesso no melhoramento de capim bermuda (Cynodon dactylon). Em todas as espécies de gramíneas que estudamos até o presente, foi encontrada variabilidade genética para DIVMO e produção de massa seca. Se melhorias na DIVMO maiores do que $1 \%$ puderem ser detectadas em estudos com parcelas pequenas $(r=6)$, pode se obter ganho diferenciado de peso de animais em função de ecotipos ou cultivares. Fazendo-se uma média entre gramíneas de estação quente e fria, aumento de $1 \%$ na DIVMO geralmente induz ganhos de peso de 3,2\%. Como o aumento da DIVMO não causa decréscimo na produção de forragem, temse aumentos no ganho líquido de produção animal por hectare. Ganhos de peso de 3,2\%. Como o aumento da DIVMO não causa decréscimo na produção de forragem, tem-se aumentos no ganho líquido de produção animal por hectare. Nas Planícies Centrais e Meio-Oeste Americano, cultivares com incremento de DIVMO podem aumentar o lucro líquido de 30 a 50 dólares por hectare.
\end{abstract}

Palavras-chave: forragem, pastagens, gramíneas, qualidade, digestibilidade, economia

\section{Introduction}

Grass breeding work was initiated by the U.S. Department of Agriculture in the Great Plains of the USA in the mid-1930's to address the ecological and agricultural damage caused by a major drought that affected large parts of North America resulting in massive soil erosion problems, particularly on lands that were only marginally suited for 
crop production (Vogel, 2004). The drought or "Dust Bowl" conditions resulted in severe wind erosion and soil drifting on cropland and loss of plants on overgrazed grasslands. By the end of the 1930's millions of hectares of crop land and damaged grasslands in the former prairie and plains states of the USA needed to be reseeded to grasses to preserve the soil and the ecosystems. One of these breeding programs was a long term cooperative USDA and University of Nebraska grass breeding project which was established to develop grass cultivars for use in the mid-continental USA. During the first forty years, the project was focused on developing adapted cultivars of an array of grasses that could be used in the different Plant Adaptation Regions of the region for conservation and grassland agriculture (Vogel et al., 2005). This work resulted in the development and release of cultivars of both native and introduced grasses including switchgrass (Panicum virgatum), big bluestem (Andropogon gerardii), indiangrass (Sorghastrum nutans), little bluestem (Schizachyrium scoparium), side-oats grama (Bouteloua curtipendula), sand lovegrass (Eragrostis trichodes), smooth bromegrass (Bromus inermis), intermediate wheatgrass (Thinopyrum intermedium), tall wheatgrass (Thinopyrum ponticum), crested wheatgrass (Agropyron cristatum), and western wheatgrass (Pascopyrum smithii).

Cultivars of different species are needed in the midcontinental USA because the region contains three major ecoregions and because both warm- $\left(\mathrm{C}_{4}\right)$ and cool- $\left(\mathrm{C}_{3}\right)$ season grasses are needed to optimize livestock production systems. In this temperate region, cool-season grasses such as the wheatgrasses and bromegrass produce most of their growth in spring, early summer, and autumn while the warm-season grasses produce most of their growth during the hot months of summer. Cool-season grasses do not produce much forage during the hot months of summer due to heat stress. The quality of forages can significantly affect animal performance and the optimal growth periods are often the periods when forage quality is high. Optimal integrated grassland, cropland, and beef cattle production systems for this region vary with Plant Adaptation Region (PAR) (Figure 1).

In PARs 251-4 \& 251-5 (Ecoregion-Hardiness Zone), which is equivalent to the former tallgrass prairie region, smooth bromegrass is one of the best adapted cool-season grasses while native prairie grasses, switchgrass, big bluestem and indiangrass are the best adapted warm-season grasses. Cool-season and warm-season grasses are seldom planted together in mixtures because they are too difficult to manage together but mixtures of cool- or warm-season grasses are often used. In PARs 331-4, 331-5, 332-4, and 3325 , which are the mid-and short-grass prairies, respectively, there are still significant areas of native rangeland that are used by cow-calf livestock producers. In these regions, lack of cool-season grasses during the spring and autumn forces livestock operators to feed harvested forages which are costly. Cool-season wheatgrasses including intermediate, tall, crested, and western wheatgrass are well adapted to these regions.

Land that was re-seeded to grasslands can be reconverted to crop production when grain prices are high. To keep margin lands in grasslands, the grasslands have to be profitable. Almost all of the grasslands in the midcontinental USA are used for beef cattle production. To be profitable, grasslands have to be productive in terms of forage yields for high stocking rates and produce high quality forage that will enable beef cattle to have good to excellent weight gains. In the early 1970's, research was initiated to improve both forage yields and quality of the primary grasses used in the region. Very limited information on breeding to improve forage quality of these grasses was available. At that time, the only grass cultivar that had been developed in the USA with improved forage digestibility was 'Coastcross 1' bermudagrass (Cynodon dactylon), as result of work by Dr. Glenn Burton (Burton et al., 1967), by selection for in vitro dry matter digestibility (IVDMD). In grazing trials, Coastcross 1 produced significantly higher animal gains than 'Coastal' bermuda grass which had lower IVDMD (Chapman et al., 1971). Bermudagrass cultivars are asexually propagated by stolons, so only a single superior plant had to be identified and increased vegetatively for testing and commercial release. In contrast, all the grasses used in the mid-continental USA are sexual polyploids that are propagated via seed. We did not know the following for grass species adapted to the mid-continental USA:

1. If IVDMD would be a good selection criteria for plants adapted to our region or if other traits would be better.

2. The phenotypic and genetic variation for IVDMD and associated traits in each species.

3. Heritability of IVDMD and associated traits.

4. The genetic correlation between yield and IVDMD.

5. When and how to effectively sample for IVDMD, because plants change throughout the growing season.

6. How many years of testing would be needed before selections are made and how many years of testing of resulting experimental lines would be needed.

7. The stability of IVDMD and associated forage traits over time and locations. 


\section{Plant Adaptation Regions of the USA}

\section{USDA Hardiness Zones}

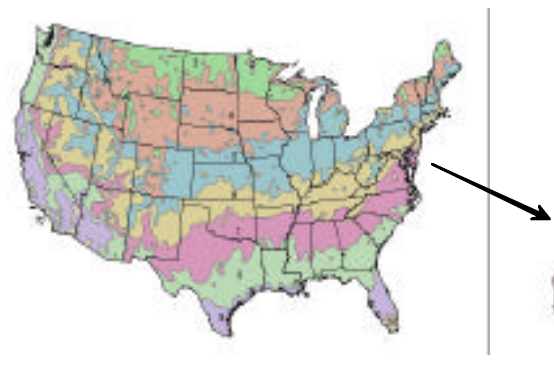

Bailey's Ecoregions

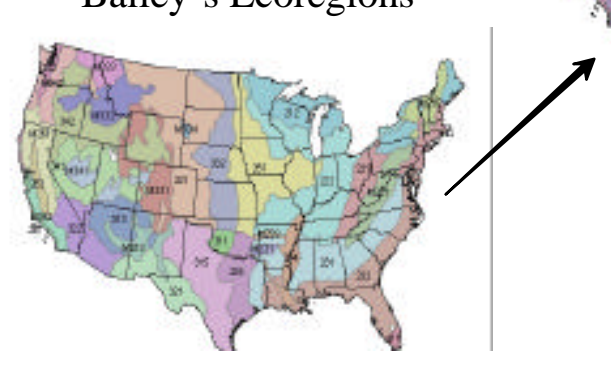

\section{Plant Adaptation}

Regions

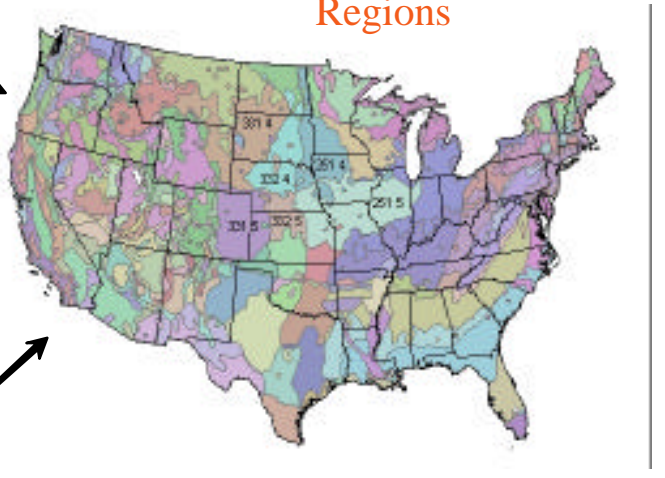

Figure 1 - Plant Adaption Regions (PAR) developed by overlaying an ecoregion map with USDA Plant Hardiness Zone map (from Vogel et al. 2005). Ecoregions are based on thermal and moisture (amount and seasonality) conditions and can cover wide zones of latitude. Latitude affects day length during the growing season, length of the growing season, and temperature during both the growing and non-growing or dormant seasons and along with physical characteristics of a region such as altitude, determines plant hardiness zones. Labeled PAR's: PAR 331-4, PAR 331-5 = Great Plains Palouse Dry Steppe HZ4 and HZ5, respectively; PAR 332-4, PAR 332-5 = Great Plains Steppe HZ 4 and HZ5, respectively; PAR 251-4, PAR 251-5 = Prairie Parkland Temperate HZ 4 and HZ5, respectively, are those for which the Lincoln USDA-ARS project is developing improved grasses. Plant Adaptation Regions can be developed for other areas of the world.

8. How much of an improvement was needed in IVDMD to result in improved animal gains on pasture.

9. The economic value of a unit improvement in IVDMD.

Basically, we did not know very much about breeding for improving forage quality to improve grassland profitability when we started this research. In this report, we describe the lessons learned in a series of studies over thirty years and how some of the research results may be applicable to South American grasslands.

\section{Breeding Research \& Lessons Learned}

The first breeding work was initiated on switchgrass by establishing space-transplanted selection nurseries in 1973 of two populations that were similar in maturity. (Vogel et al.,1981a). In comparison to the other adapted grasses, switchgrass has a smooth, shiny seed, that is easy to clean and plant and it is a good seed producer. It is easier to work with in breeding and genetic studies than the other adapted species. In 1974, 400 healthy, vigorous plants were sampled for IVDMD when the panicles were beginning to emerge from the boot or R2 stage (Moore et al., 1991). Five whole tillers were collected per plant by cutting them at $5 \mathrm{~cm}$ above the bases of the plant. Sampled tillers were dried, ground, and analyzed for IVDMD using the Tilley and Terry (1963) procedure in the Agronomy Analytical Lab of the University of Nebraska. We decided to use IVDMD as the breeding criteria to improve forage quality because Burton and his colleagues had demonstrated that it was effective in improving animal performance in bermudagrass and we had access to a laboratory than conducted IVDMD analyses.

In 1974 and 1975, 220 plants that had the highest and lowest IVDMD values were re-sampled with an equal number of plants sampled per nursery row. By early 1976, three years of IVDMD data was available on 220 plants. There was a phenotypic range of about $60 \mathrm{mg} \mathrm{g}^{-1}$ for IVDMD among the sampled plants for $3 \mathrm{yr}$ means (Vogel et al., 1981b). We (Herman Gorz, Francis Haskins, andKen Vogel) had established that phenotypic variation existed in switchgrass for IVDMD and we decided that probably the easiest and most reliable method to use to determine if the phenotypic variation for IVDMD in switchgrass was heritable was to do divergent breeding for IVDMD. We selected 25 high and 25 low IVDMD plants from the two populations, divided them into two ramets (a clonal piece) each and transplanted them into isolated polycross nurseries in 1976, allowing them to naturally intermate via wind pollination. In 
Table 1 - Mean forage yields, forage IVDMD, and forage in vivo digestibility in sheep for switchgrass strains divergently bred for IVDMD (from Vogel et al, 1981b, Vogel et al., 1984)

\begin{tabular}{lccccc}
\hline Strain & $\begin{array}{c}\text { Yield Mg ha } \\
\text { 1978-1980 means }\end{array}$ & $\begin{array}{c}\text { IVDMDg kg-1 } \\
\text { In vivo digestibilityg kg-1 } \\
\text { Sheep trials with 1980 forage harvest }\end{array}$ & $\begin{array}{c}\text { Dry matter intakeg } \mathrm{kg}^{-1} \\
\text { Fiber digestibilityg kg-1 }\end{array}$ \\
\hline High IVDMD PC & 9.7 & 506 & 504 & 683 & 559 \\
Pathfinder & 9.3 & 477 & 508 & 718 & 570 \\
Low IVDMD PC & 9.7 & 467 & 490 & 674 & 541 \\
LSD 0.05 & NS & 19 & NS & NS & NS \\
\hline
\end{tabular}

${ }^{1}$ Pathfinder is a cultivar similar to the base population of the experimental strains.

${ }^{2} \mathrm{NS}=$ not significant. There were no significant differences among the stains for NDF, ADF, and ADL (data not shown).

1977, seed was harvested from each plant in the polycross nurseries and an equal amount of seed was composited from each plant to form a high and low IVDMD PC composite population for use in establishing a sward evaluation trial and subsequent breeding nurseries. We did not know how many replicates we would need in a small sward plot yield test to be able to detect differences in forage IVDMD so we planted the maximum number of replicates $(r=7)$ feasible with our seed supply in the spring of 1978 (Vogel et al., 1981). The replicated trial was managed using best known management practices. Forage yields were harvested in 1978, 1979, and 1980, at the R1 or R2 maturity stages. All the forage from the 1980 harvests was collected and dried for use in an in vivo feeding trial with sheep (Vogel et al., 1984). The High IVDMD PC strain had significantly higher forage IVDMD than the control cultivar, Pathfinder, and the Low IVDMD PC strain (Table 1). There were no differences among the strains in the trial for forage yield, neutral detergent fiber (NDF), acid detergent fiber (ADF), or acid detergent lignin (ADL) (data not shown) (Vogel et al., 1984). Although the High IVDMD PC strain had higher in vivo digestibility, dry matter intake, and fiber digestibility than the Low IVDMD PC strain in the sheep feeding trial, the differences were not statistically significant (Table 1) (Vogel et al., 1984). Realized heritability for high and low IVDMD, respectively were 0.59 and 0.55 , respectively (Vogel et al., 1981b).
Although we did not find significant differences in in vivo digestibility, we decided to proceed with a beef cattle grazing trial. Based on the 1978 IVDMD results from the small plot trials, seed increase nurseries were established and by the spring of 1981 sufficient seed had been produced to plant a replicated $(r=4)$ pasture trial containing the High IVDMD PC, Pathfinder, and Low IVDMD PC strains. At the time of the trial, Pathfinder was the best available switchgrass cultivar for the region. The paddock size ( 0.4 ha) was determined by seed, land, and animal availability rather than previous knowledge of animal numbers needed to detect statistical differences. Good stands were obtained in 1981 and the grazing study was initiated in 1982 in which best agronomic management practices were used including fertilization with $112 \mathrm{~kg} \mathrm{ha}^{-1} \mathrm{~N}$. The grazing trial was a cooperative team effort or University of Nebraska agronomists and animal scientists, and USDA-ARS plant geneticists (Anderson et al., 1988). Animal production data was obtained in 1982, 1983, and 1985. In 1984, the pastures were grazed with esophageal fistulated animals to determine if there were any differences in selectivity by animals among the strains. The stocking rate was based on the forage yields obtained in the small plot trials. Pastures were grazed continuously by three randomly allotted beef cattle yearlings in 1982 and 1983 and by 4 yearlings in 1985 with average initial animal weight of 300 to $315 \mathrm{~kg}$. The genetic improvements in IVDMD that were achieved without any reductions in forage yield resulted in significant

Table 2 - Performance of beef yearlings grazing switchgrass strains bred for differences in IVDMD in 1982, 1983, and 1985. Data listed are three year means (Anderson et al., 1984)

\begin{tabular}{|c|c|c|c|c|c|}
\hline \multirow[t]{2}{*}{ Strain } & \multicolumn{2}{|c|}{ Beef cattle gains } & \multirow{2}{*}{$\begin{array}{l}\text { Available forage } \\
\qquad \mathrm{kg} \mathrm{ha}^{-1}\end{array}$} & \multicolumn{2}{|c|}{ Forage IVDMD } \\
\hline & Gain ha ${ }^{-1} \mathrm{~kg} \mathrm{ha}^{-1}$ & $\mathrm{ADG}^{1} \mathrm{~kg} \mathrm{ha}^{-1}$ & & Available $\mathrm{g} \mathrm{kg}^{-1}$ & $\mathrm{Tops}^{3} \mathrm{~g} \mathrm{~kg}^{-1}$ \\
\hline High IVDMD PC (Trailblazer) & 315 & 0.73 & 3420 & 580 & 602 \\
\hline Low IVDMD PC & 299 & 0.64 & 3160 & 555 & 565 \\
\hline $\mathrm{P}<$ & 0.05 & 0.05 & 0.05 & 0.05 & 0.05 \\
\hline SEM & 13 & 0.07 & 38 & 12 & 12 \\
\hline
\end{tabular}

1 ADG = average daily gain per animal.

${ }^{2}$ Available forage was based on weekly quadrant samples clipped at a height of $2.5 \mathrm{~cm}$.

${ }^{3}$ Tops is the top $1 / 3$ of canopy which the animals were selectively grazing. 
improvements in beef cattle average daily gains and gains per hectare (Table 2). Because there are no additional costs associated with the improved gains due to improvements in IVDMD, the gains represent improvements in net profits.

The pastures were sampled weekly during the grazing trial. Switchgrass is a strongly determinate species and its forage increases in maturity even when being grazed. As the forage inceases in maturity, lignification increases and IVDMD decreases (Jung and Vogel, 1992; Mitchell et al., 2001). The grazed switchgrass forage in the pastures declined during the grazing season but the differential among the strains for IVDMD was consistent (Anderson et al, 1988). The cattle in the trial selectively grazed the tops of the canopy. The forage from the top one-third of the canopy, "Tops", was higher in IVDMD than the total available forage (Table 2). Extrusa selected from espophageally fistulated steers during the 1984 grazing season had higher IVDMD (764 $\left.\mathrm{g} \mathrm{kg}^{-1}\right)$ than from the top $\left(677 \mathrm{~g} \mathrm{~kg}^{-1}\right)$ and available forage $\left(645 \mathrm{~g} \mathrm{~kg}^{-1}\right)$ (Ward et al., 1989). Steers did not differently select a higher IVDMD diet from one strain than another. Over the years, the ranking of the strains for IVDMD was consistent regardless of the pasture sampling method. Subsequent genotype $x$ environment studies has demonstrated that IVDMD in switchgrass is a very stable trait over environments (Hopkins et al., 1995 a,b).

The "High IVDMD PC" strain was released as the cultivar 'Trailblazer' based on the improved gains achieved in the grazing trial (Vogel et al., 1991). It was been the most widely planted switchgrass in the Great Plains in the twenty years following its release (Casler \& Vogell, 1999). Additional breeding work has been conducted for both IVDMD and forage yield and IVDMD in several different switchgrass populations. In the original high IVDMD population, significant improvements in IVDMD were made in two additional breeding generations (Hopkins et al, 1993). However, the cycle 3 population had reduced forage yield and significantly reduced winter survival (Casler et al., 2002) although some families within the population had good winter survival and high IVDMD (Vogel et al., 2002). In all other switchgrass populations, breeding for both improved forage yield and IVDMD has been conducted. A simple selection index (NI for Nebraska Index) has been used which weights forage and IVDMD equally as shown in the equation:

$\mathrm{NI}=(($ yield - mean yield $) / \mathrm{SD}$ yield $)+(($ IVDMD - mean IVDMD)/SDIVDMD)

(Equation 1)
Table 3 - Breeding progress in developing switchgrass cultivars with improved forage yield and in vitro dry matter digestibility (IVDMD) illustrated with data from a forage trial at Mead, Nebraska, USA during the period 2003-2005

\begin{tabular}{lccc}
\hline Cultivar & $\begin{array}{c}\text { Year } \\
\text { released }\end{array}$ & $\begin{array}{c}\text { Forage yield } \\
\mathrm{Mg} / \mathrm{ha}\end{array}$ & IVDMDg/kg \\
\hline Trailblazer & 1984 & 14.1 & 525 \\
Shawnee & 1995 & 14.5 & 548 \\
NE Late YD C4 & In seed increase & 15.7 & 552 \\
$\quad$ & & 0.8 & 10 \\
\hline
\end{tabular}

where SD is the standard deviation. Individual plant yields and IVDMD values are used to calculate the NI values.

For a population of plants, the mean NI value is zero, the desirable plants with high yields and IVDMD have positive NI values while the plants with low yields and low IVDMD values have negative NI values. The improvements that have been achieved by breeding for both forage yield and IVDMD in switchgrass are illustrated in Table 3. The strain that is currently being increased for release, NE Late YD C4, has $1.6 \mathrm{Mg} \mathrm{ha}^{-1}$ greater forage yield than Trailblazer and its forage is $27 \mathrm{~g} \mathrm{~kg}^{-1}$ higher in IVDMD. In populations in which both forage yield and IVDMD are selection criterion, there have not been any problems with winter survival or other fitness traits. In switchgrass, released gains from breeding have been somewhat less than those expected based upon heritability estimates and phenotypic variances (Hopkins et al., 1993).

In addition to the work on switchgrass, research on other warm- and cool-season grasses indicate that there is substantial genetic variation for both forage yield and IVDMD in big bluestem, indiangrass, smooth bromegrass, and intermediate tall, and crested wheatgrass and that the differences in IVDMD are stable over environments (Lamb et al., 1994; Vogel, 1983; Vogel et al., 1981a, 1984, 1986, 1993; Casler et al., 2001; Mitchell et al., 2005). Genetic correlations between IVDMD and forage yield are typically either slightly negative or neutral. Six replicates are usually needed in small plot sward trials to detect significant differences $(\mathrm{P}<$ 0.05 ) among experimental strains and cultivars for IVDMD.

Grazing trials with intermediate wheatgrass (Moore et al., 1995), (data not shown ) and big bluestem (Mitchell et al., 2005), see Table 4 ) demonstrated that the results from the switchgrass grazing trial are applicable to other grasses. In the first phase of the big bluestem breeding program, two older, reliable big bluestem cultivars with broad genetic bases, Pawnee and Kaw, were bred for improved forage yield and IVDMD for three generations each. Pawnee is 
Table 4 - Beef production, average daily gain (ADG), gross return, and the economic value of improvement for four big bluestem cultivars grazed with 7.5 steers/ha in 2000, 2001, and 2002 at Mead, NE. (from Mitchell et al., 2005)

\begin{tabular}{lcccc}
\hline Cultivar & Beef production (kg/ha) & ADG (kg/hd/d) & Gross return(US\$/ha) & Value of improvement(US\$/ha) \\
\hline Pawnee & 398 & 1.12 & 340 & 109 \\
Bonanza (Pawnee C3 & 455 & 1.30 & 449 & 39 \\
Kaw & 424 & 1.19 & 392 & 431 \\
Goldmine (Kaw C3) & 444 & 1.27 & & 39 \\
\hline
\end{tabular}

best adapted to USDA Plant Hardiness Zone 5 and lower Hardiness Zone 4 while Kaw is best adapted to Hardiness Zone 6 and lower Hardiness Zone 5. The three generations of breeding resulted in strains Pawnee $\mathrm{C} 3$ and Kaw $\mathrm{C} 3$ which improved beef cattle average daily gains (ADG) and gains per hectare in comparison to their parent cultivars in a replicated grazing trial (Table 4) (Mitchell et al., 2005). More improvements were made in the Pawnee $\mathrm{C} 3$ strain than in the Kaw C3 strain. The Pawnee C3 and Kaw C3 strains were released as the cultivars 'Bonanza' and 'Goldmine', respectively.

The breeding work and the animal trials that we have conducted demonstrate that improving forage digestibility while maintaining or improving forage yield significantly improves animal performance, which has very positive effects on profitability of livestock production systems (Casler \& Vogel, 1999; Mitchell et al., 2005). Averaged over both cool- and warm-season grasses, a $1 \%$ increase in in vitro dry matter digestibility (IVDMD) generally leads to a $3.2 \%$ increase in average daily gains of beef cattle (Casler $\&$ Vogel, 1999). Because increased IVDMD generally does not result in a decrease in forage yield, this results in a net increase in animal production per hectare of land. In the Central Plains and Midwest, cultivars with improved IVDMD can increase net profit from $\$ 30$ to $\$ 50 \mathrm{ha}^{-1}$. In addition to the cultivars described previously, other cultivars that have been released with improved forage yield and IVDMD include 'Beefmaker' intermediate wheatgrass and 'Scout' and 'Warrior' indiangrass. Experimental strains of other grasses with improved IVDMD and forage yield are in seed increase for potential release.

\section{Current breeding program methods and procedures}

Breeding perennial species requires a long term, multistep plan and use of efficient breeding systems (Vogel and Pedersen, 1993; Vogel \& Burson, 2004). The breeding schedule that is followed in the USDA-ARS project at the University of Nebraska is summarized in Table 5. A comprehensive breeding program requires a germplasm evaluation phase which can be on-going, a phase that includes multi-step selection and mating systems, a small plot evaluation phase in which the limited quantities of breeder seed are used to evaluate breeding progress in small plot sward trials, and ideally, a phase in which the experimental strains are evaluated in grazing trials. Polycross nurseries or seed increase nurseries are required to advance from phase-to-phase to final cultivar release. Although the typical time interval for a phase is five years, the duration of a phase can be extended because of adverse weather conditions or to obtain additional data or seed. The two main breeding systems that are used in this program are Recurrent Restricted Phenotypic Selection (RRPS), which is also known as Stratified Mass Selection (RSMS) (Figure 2); and Between and Within Half-sib Family Selection (B\&WFS) (Figure 3) (Vogel \& Pedersen, 1993; Vogel \& Burson, 2004). Recurrent mass selection is being used in the initial step of the breeding phase when new germplasm is being incorporated into a population. Selection nurseries are space-transplanted with plants on $1.1 \mathrm{~m}$ centers. Plants selected from the first cycle of RRPS are moved to polycross nurseries. Seed is harvested from individual genotypes to form half-sib families. The grasses are all cross-pollinated so intermated plants in polycross nurseries produce half-sib seed. The B\&WFS system is then used.

Both methods are efficient breeding systems and fully utilize all additive genetic variation (Vogel \& Pedersen, 1993). The B\&WFS method allows the breeder to obtain estimates of existing genetic variation each cycle and by including the parent population and check entries to monitor breeding progress (Vogel \& Pedersen, 1993; Vogel and Burson, 2004). It will take two or three breeding generations or cycles before significant differences can be detected in small plot trials. If significant improvements have been demonstrated in small plot trials, the improvements will usually result in significant improvements in animal gains in grazing trials for the grasses adapted to the mid-continental USA. Forage quality for all selection nurseries and evaluation trials is measured using the filter bag systems for IVDMD (Vogel et al., 1999) on sample sets that are then used to develop near infra-red spectroscopy (NIRS) prediction calibrations for predicting quality on all samples. This has proven to be a reliable method of handling large numbers of samples. 


\section{RECURRENT, STRATIFIED, MASS SELECTION}

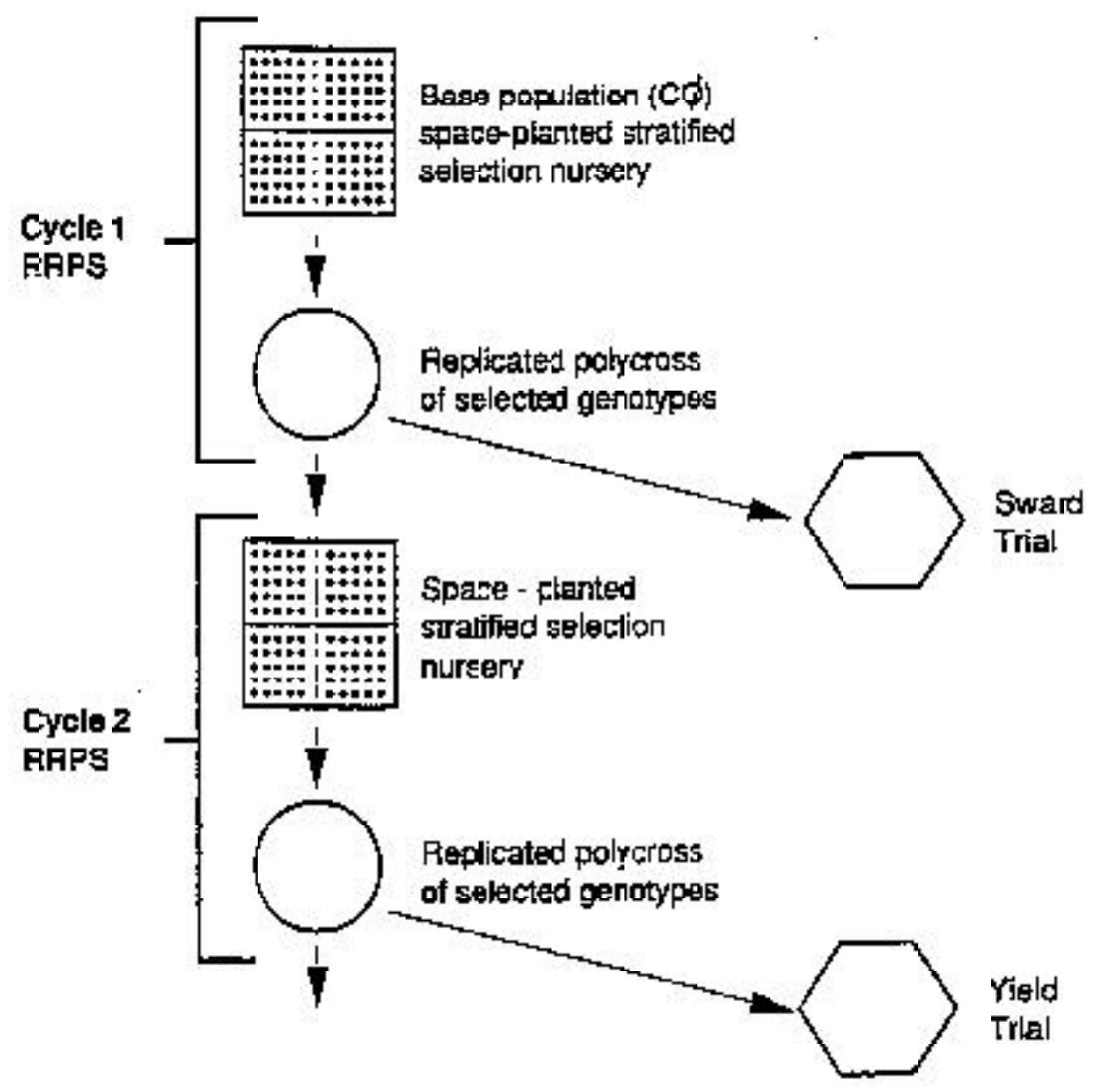

Figure 2 - Recurrent, stratified mass selection which is sometimes known as Restricted, Recurrent Phenotypic Selection (RRPS) (from Vogel \& Pedersen, 1993).

\section{Applications to South American grasslands}

Most of the grasses that are being used in the midcontinental USA are obviously not adapted to many areas of South American. Many of the grasses adapted to South American grasslands are also apomictic and different breeding systems are needed (Vogel \& Burson, 2004). The common aspect to grassland research for South American and USA grasslands is both predominately use beef cattle to harvest and produce meat from grazed grasses. Improvements in forage digestibility of grasses adapted to South America should produce the same improvements in cattle daily gains and gains per hectare as that achieved in the mid-continental USA. Small improvements in forage digestibility can have big improvements in cattle gains as documented in Tables 2 and 4 because of the reason illustrated in Figure 4. Cattle can only eat a limited volume of forage.
The energy in that volume first has to satisfy their basal metabolic requirements before they can gain weight or produce milk. As the digestibility or availability of energy per unit mass increases, body weight gains or milk production increases exponentially. In addition to improving the amount of energy extracted from a unit mass of forage, the forage may be digested faster improving the rate of passage which allows the animal to graze more often resulting in additional gains. In addition, some of the NIRS calibrations may be transferable between species. We have analyzed some Brachiaria brizantha cv. Marandu and four different Panicum maximum cultivars samples from Brazil with our NIRS forage quality calibrations for switchgrass (Panicum virgatum) and found that they are fully useable, with a good fit with the calibrations already in use in Embrapa Beef Cattle. Other technical aspects of our grassland research also may be directly applicable to 


\section{RECURRENT BETWEEN AND WITHIN \\ HALF-SIB FAMILY SELECTION (B \& W FS)}

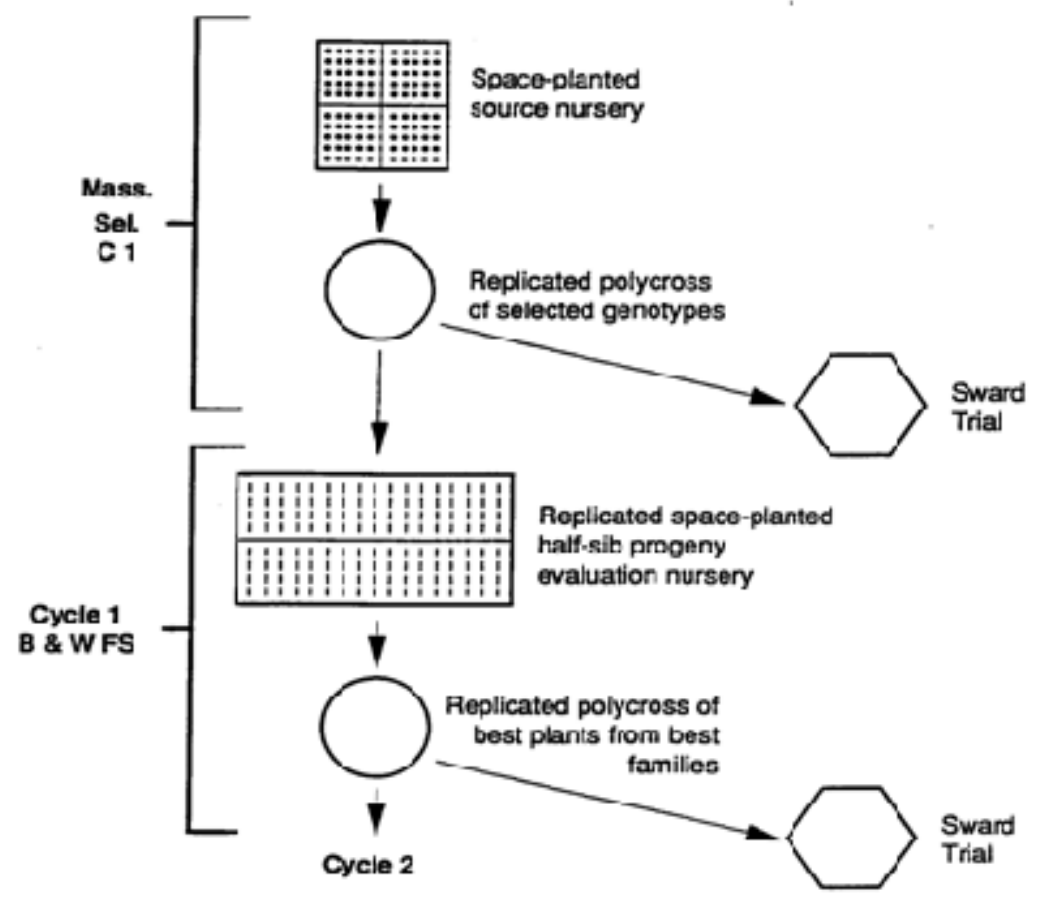

Figure 3 - Recurrent, between and within half-sib family selection (B\&WFS) (from Vogel \& Pedersen, 1993).

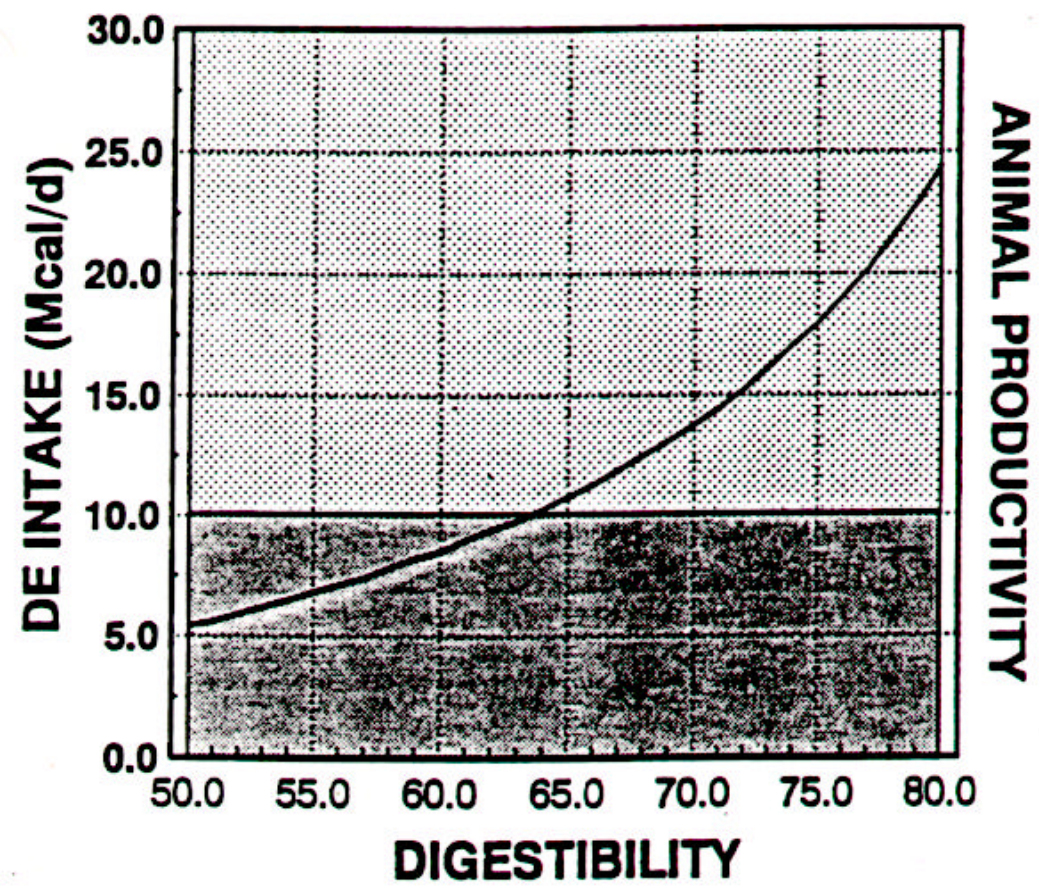

Figure 4 - Animal productivity increases exponentially with improvements in forage digestibility. Digestible energy (DE) intake values are for a $300 \mathrm{~kg}$ beef steer. The darker shaded area represents maintenance requirements (from Vogel \& Moore, 1993). 
grassland research in South America.

\section{Literature Cited}

ANDERSON, B.; WARD, J.K.; VOGEL, K.P. et al. Forage quality and performance of yearlings grazing switchgrass strains selected for differing digestibility. Journal of Animal Science, v.66, p.2239-2244, 1988

BURTON, G.W.; HART, R.W.; LOWREY, R.S. Improving forage quality of bermudagrass by breeding. Crop Science, v.14, p.831$835,1967$.

CASLER, M.D.; BUXTON, D.R.; VOGEL, K.P. Genetic modification of lignin concentration affects fitness of perennial herbaceous plants. Theorical Applied Genetics, v.104, p.27$131,2002$.

CASLER, M.D.; VOGEL, K.P. Accomplishments and impact from breeding for increased forage nutritional value. Crop Science, v.39, p12-20, 1999.

CASLER, M.D.; VOGEL, K.P.; BALASKO, J.A. et al. 1. Latitudinal and longitudinal adaptation of smooth bromegrass populations. Crop Science, v.41, p.456-1460, 2001

CHAPMAN, H.D.; MARCHANT, W.H.; BURTON, G.W. et al Performance of steers grazing Pensacola bahiagrass, Coastal, and Coastcross 1 bermudagrass. Journal of Animal Science, v.32, p374-378, 1971.

HOPKINS, A.A.; VOGEL, K.P.; MOORE, K.J. Predicted and realized gains from selection for in vitro dry matter digestibility and forage yield in switchgrass. Crop Science, v.33, p.253-258, 1993.

HOPKINS, A.A.; VOGEL, K.P.; MOORE, K.J. et al. Genotype effects and genotype by environment interactions for traits of elite switchgrass populations. Crop Science, v.35, p.125-132, 1995.

HOPKINS, A.A.; VOGEL, K.P.; MOORE, K.J. et al. Genetic variability and genotype $\mathrm{x}$ environment interactions among switchgrass accessions from the Midwestern USA. Crop Science, v.35, p.565-571, 1995.

JUNG, H.G; VOGEL, K.P. Lignification of switchgrass (Panicum virgatum L.) and big bluestem (Andropogon gerardii) plant parts during maturation and its effect on fibre degradability. Journal of Science Food Agriculture, v.59, p.169-176, 1992.

LAMB, J. F. S.; VOGEL, K.P.; REECE, P.E.. Genotype and genotype $\mathrm{x}$ environment interaction effects on forage yield and quality of crested wheatgrass. Crop Science, v.24, p559 564, 1984.

MITCHELL, R.B.; FRITZ, J.O.; MOORE, K.J. et al. Predicting forage quality in switchgrass and big bluestem. Agronomy Journal, v.93, p118-124, 2001.

MITCHELL, R.B.; VOGEL, K.P.; KLOPFENSTEIN, T.J. et al. Grazing evaluation of big bluestems bred for improved forage yield and digestibility. Crop Science, v.45, p.2288-2292, 2005.

MOORE, K.J.; MOSER, L.E.; VOGEL, K.P. et al. Describing and quantifying growth stages of perennial forage grasses. Agronomy Journal, v.83, p1073-1077, 1991.

MOORE, K.J.; VOGEL, K.P.; KLOPFENSTEIN, T.J. et al. Evaluation of four intermediate wheatgrass populations under grazing. Agronomy Journal, v.87, p.744-747, 1995.

TILLEY, J.A.; TERRY, R.A. A two-stage technique of the in vitro digestion of forage crops. Journal of British Grassland Society, v.18, p. 104-111, 1963.

VOGEL, K.P. Evaluation of the bromegrass introductions for forage yield and quality. Nebrasca Agricultural Experimental Station, 1983. p.1-13. (Research Bulletin, 300).

VOGEL, K.P. Humans, climate, and plants: the migration of crested wheatgrass and smooth bromegrass to the Great Plains of North America. In: WERNER, D. (Ed.) Biological resources and migration. Springer-Verlag, Berlin: 2004. p.35-45.

VOGEL, K.P.; BRITTON, R.; GORZ, H.J. et al. In vitro and in vivo analyses of hays of switchgrass strains selected for high 
and low IVDMD. Crop Science, v.24, p.977-980, 1984.

VOGEL, K.P.; BURSON, B. Breeding and genetics. In MOSER, L.E.; SOLLENBERGER, L.; BURSON, B. (Eds.). Warmseason $\left(\mathbf{C}_{4}\right)$ grasses. Madison: ASA-CSSA-SSSA Monograph, 2004. p.51-96.

VOGEL, K.P.; GORZ, H.J.; HASKINS, F.A. Heritability estimates of forage yield, in vitro dry matter digestibility, crude protein, and heading date in indiangrass. Crop Science, v.21, p.35$38,1981 \mathrm{a}$.

VOGEL, K.P.; GORZ, H.J.; HASKINS, F.A. Divergent selection for in vitro dry matter digestibility in switchgrass. Crop Science, v.21, p.39-41, 1981b.

VOGEL, K.P.; HASKINS, F.A.; GORZ, H.J. et al. Registration of 'Trailblazer' switchgrass. Crop Science, v.31, p.1388, 1991.

VOGEL, K.P.; HOPKINS, A.A.; MOORE, K.J. et al. Winter survival in switchgrass populations bred for high IVDMD. Crop Science, v.42, p.1857-1862, 2002a.

VOGEL, K.P.; MOORE, K.J. Native North American grasses. In: JANICK, J.; SIMON, J.E. (Eds.). New crops. New York: John Wiley and Sons, 1993. p.284-293.

VOGEL, K.P.; PEDERSEN, J.F. Breeding systems for crosspollinated perennial grasses. Plant Breeding Reviews, v.11, p.251-274, 1993.
VOGEL, K.P.; PEDERSEN, J.F.; MASTERSON, S.D. et al. Evaluation of a filter bag system for NDF, ADF, and IVDMD forage analysis. Crop Science, v.39, p.276-279, 1999.

VOGEL1, K. P.; REECE, P.E.; LAMB, J.F.S. Evaluation of crested wheatgrass introductions for forage yield and quality. Nebrasca Agricultural Experimental Station, 1983. p.21-33. (Research Bulletin, 300).

VOGEL, K.P.; REECE, P.E.; LAMB, J.F.S. Genotype and genotype $x$ environment interaction effects for forage yield and quality of intermediate wheatgrass. Crop Science, v.26, p.653-658, 1986.

VOGEL, K.P.; REECE, P.E.; NICHOLS, J.T. Genotype and genotype $x$ environment interaction effects on forage yield and quality of intermediate wheatgrass in swards. Crop Science, v.33, p.37-41, 1993.

VOGEL, K.P.; SCHMER, M.R.; MITCHELL, R.B. Plant adaptation regions: ecological and climatic classification of plant materials. Rangeland Ecology and Management, v.58, p.315-319, 2005.

WARD, M.G.; WARD, J.K.; ANDERSON, B.E. et al. Grazing selectivity and in vivo digestibility of switchgrass strains selected for differing digestibility. Journal of Animal Science, v.67, p.1418-1424, 1989. 